\title{
39. VELOCITY-DENSITY SYSTEMATICS FOR BASALTS DRILLED ON THE EAST PACIFIC RISE AND GALAPAGOS RIFT DURING DEEP SEA DRILLING PROJECT LEG 54
}

\author{
Nick Warren, Department of Geology, University of California, Los Angeles \\ and
}

Bruce R. Rosendahl, Department of Geology, Duke University, Durham, North Carolina

\begin{abstract}
Precise velocity and density measurements at atmospheric and elevated pressures have been obtained on basalts drilled in 13 holes during Leg 54. The $v_{p}$-e data show systematics which are controlled by the degree of crystallinity (or conversely, glassiness), microstructure, and original mineralogy and chemistry. Extensively fractionated basalts with marked iron enrichment produce anomalously low measured velocities at densities above $2.90 \mathrm{~g} / \mathrm{cm}^{3}$. Also, the effective in situ pressure acting on Leg 54 basalts is less than hydrostatic, and perhaps close to zero. At zero effective pressure, the measured velocities average $2.5 \mathrm{~km} / \mathrm{s}$ higher than East Pacific Rise upper crustal velocities determined by seismic refraction. This implies that the in situ velocities are undoubtedly a result of the highly fragmented nature of East Pacific Rise crust.
\end{abstract}

\section{INTRODUCTION}

The original goal of Leg 54 - to establish a "type ection" for crust produced at the fast-spreading East ?acific Rise (EPR) - could not be achieved for reasons liscussed elsewhere (see Chapter 1). Instead, during Leg 54 the Glomar Challenger drilled a large number of single-bit, short-penetration holes. From our perspective, this proved to be a boon because it provided us with the opportunity to make a large number of shipboard velocity and density measurements on basalt samples from 13 separate basement localities. These measurements, supplemented with shore-based density determinations on 28 samples and velocity-pressure measurements on four samples, enabled us to establish velocity-density systematics for each site and for both the EPR and Galapagos Spreading Center (GSC) site groupings. The results of our work are presented herein and compared with velocity-density data obtained from earlier drilling on the Mid-Atlantic Ridge and with velocity data obtained from seismic refraction experiments in the Leg 54 drilling areas.

\section{Locales}

The drill sites on Leg 54 were located in two general regions, on the west flank of the EPR at $9^{\circ} \mathrm{N}$ and on the flanks of the GSC in the vicinity of $87^{\circ} \mathrm{W}$. Within these two regions there are sub-areas, or locales, between which the physical properties of the basalts have basic similarities. Table 1 lists locales and Figure 1 shows the geographical locations of the sites.

\section{SAMPLE PREPARATION AND TECHNIQUES}

The techniques used in determining velocities and densities on shipboard are described in the introductory chapter of this volume. Additional shore-based velocities and densities were measured in the rock physics laboratory at UCLA. Both grain densities and bulk densities were determined.

The Archimedean principle was used to measure grain density. Samples were washed with soapy water, and subsequently in distilled water in an ultrasonic cleaner. They were then dried in a near vacuum at $100^{\circ} \mathrm{C}$ for three days. Finally, the samples were crushed with a ram and powdered in a shaker for 2 minutes.

Ten-milliliter Fisher specific gravity bottles were used, for which the volumes of the bottles and their capillary stoppers were accurately determined at a given temperature with double-distilled water.

The mass determinations were made on a Mettler type $\mathrm{H} 16$ electronic balance with 80 gram capacity. Reproducibility of the measurements of the masses of the dry bottles and the samples was $\pm 5 \cdot 10^{-5}$ grams.

TABLE 1

Locales of Drill Sites, Leg 54

\begin{tabular}{llll}
\hline Region & \multicolumn{1}{c}{ Locale } & Hole & $\begin{array}{c}\text { Approximate Age } \\
(\mathrm{m} . \mathrm{y} .)\end{array}$ \\
\hline EPR & Normal fabric & 420 & 3.0 \\
& & 421 & $2.0-2.1$ \\
& & 423 & 1.4 \\
& & $429 \mathrm{~A}$ & 4.3 \\
& "Moat" of the OCP & 422 & 1.63 \\
& Ridge & 428 & 1.8 \\
& & $428 \mathrm{~A}$ & 1.8 \\
& Siqueiros fracture & 427 & 1.3 \\
& zone & & \\
GSC & Mounds hydrothermal area & 424 & 0.6 \\
& North flank & $424 \mathrm{~A}, \mathrm{~B}, \mathrm{C}$ & 0.6 \\
& & 425 & 1.94 \\
\hline
\end{tabular}




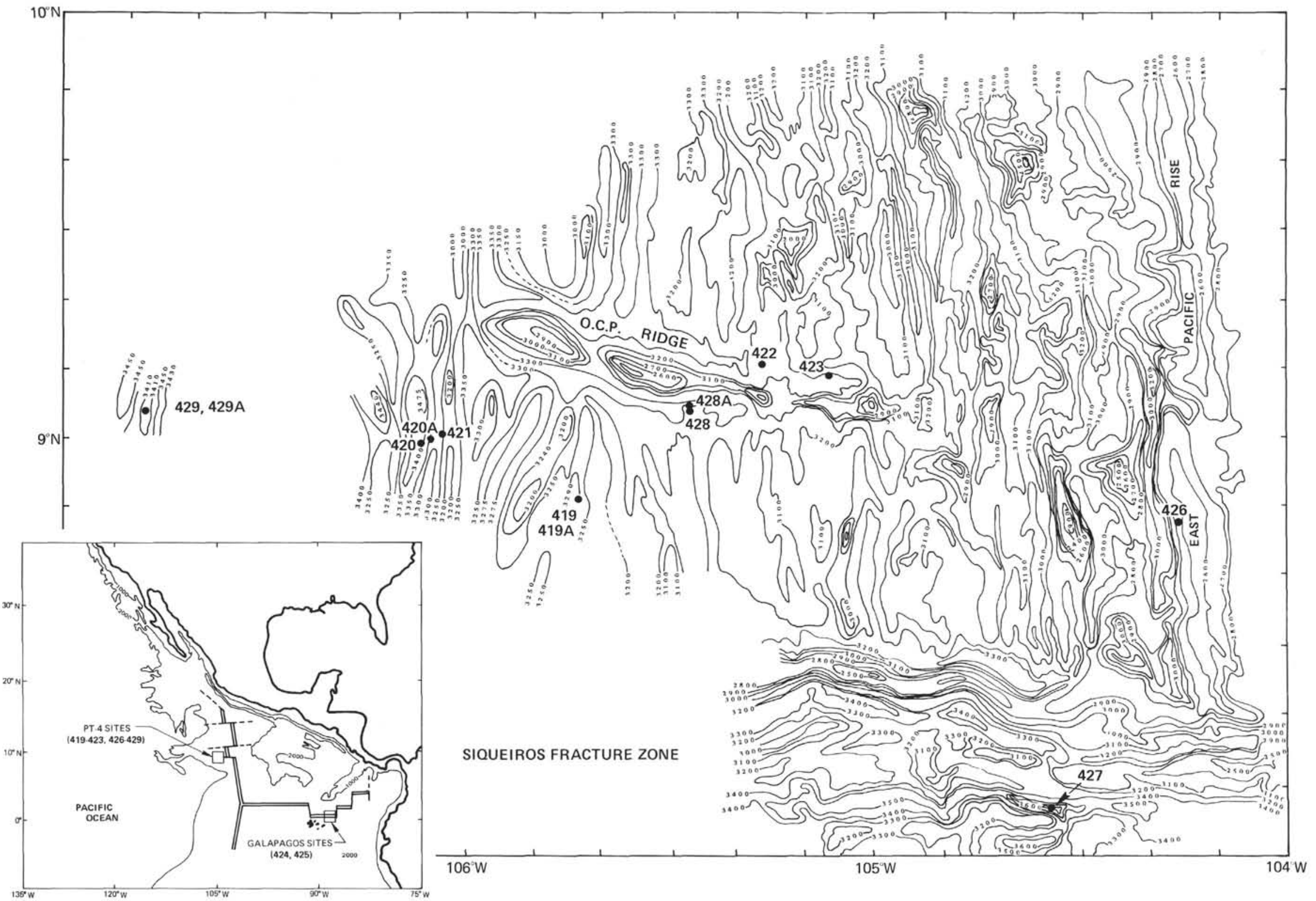

Figure 1. Leg 54 drilling sites on the west flank of the EPR. Inset: location of Leg 54 principal target areas in the eastern Pacific. 
Reproducibility of the measurements of liquid-filled bottles and of the water volume was $\pm 10^{-4}$ grams and $10^{-4} \mathrm{~cm}^{3}$, respectively. The error of the grain density calculation is less than 0.2 per cent.

For the bulk density measurement, the samples were accurately cored $( \pm 0.008 \mathrm{~mm})$, parellel faced $( \pm 0.008$ $\mathrm{mm}$ ), and polished; they were washed and dried as in the grain density procedure. The dimensions were determined with micrometer calipers, and the volume calculated. The mass of the sample was also determined, as with the grain density procedure, to $\pm 10^{-5}$ grams. The error of the bulk density calculation is less than 0.3 per cent.

Compressional wave velocities at high pressure (up to $4 \mathrm{kbar}$ ) were measured on a number of dried minicores. A pulse transmission method was used (Mattaboni and Schreiber, 1967). The time delay of the signal through the sample was determined by an electronic delay-line technique recently developed in our laboratory.

Table 2 gives the estimated and/or measured accuracies and precisions of these measurements, and can be used to judge their reliability.

\section{MINERALOGIES}

Table 3 summarizes the available shipboard mineralogies for the samples studied here. Data for Site 420 are not included. There was very low rock recovery at that site, and the measured velocities (given in the Site Report) were not accurate enough for this study.

\section{DENSITIES AND VELOCITIES}

Tables 4 and 5 give a listing of the dry-bulk densities and grain densities for all sites studied, including both shipboard and laboratory data.

The velocity-wet bulk density data compilations, the original velocity data, and specific discussions are all given in the Site Reports, this volume. It is the relationship between the velocity and wet-bulk density that we are mainly concerned with in this study. In the following section, these parameters have been plotted against outlines of fields which contain the velocity-density distributions in the locales given in Table 1. The fields were defined by the shipboard data as follows: field 1; Holes 421 and 423: field 2; Hole 422: field 3; Hole 424: field 4; Holes 424A, B, and C: field 5; Hole 425.

\section{BIRCH SYSTEMATICS}

\section{General}

Plots of the compressional wave velocity $\left(V_{p}\right)$ versus wet-bulk densities for our samples generate well-defined Birch law relationships. This is surprising because zeropressure data for oceanic basalts usually show a great deal of scatter. Indeed, even at pressures up to $0.5 \mathrm{Kbar}$ data still need not demonstrate Birch law systematics.

In order to discern why Birch law relationships seem to hold for our zero-pressure data, a brief background discussion is warranted. Birch law systematics are (to a first order) a linear relationship between a rock's velocity and density (Birch, 1961). The general nature of the empirical relationship is well established and has been
TABLE 2

Precision and Accuracy of Measurements

\begin{tabular}{|c|c|}
\hline \multicolumn{2}{|l|}{ Shipboard Measurements } \\
\hline \multicolumn{2}{|l|}{ Minicores } \\
\hline $\begin{array}{l}\text { length } \\
\text { diameter } \\
\text { mass }\end{array}$ & $\begin{array}{l} \pm 0.02 \mathrm{~mm} \\
\pm 0.01 \mathrm{~mm} \\
\pm 0.005 \mathrm{gm}\end{array}$ \\
\hline \multicolumn{2}{|l|}{ Velocity } \\
\hline $\begin{array}{l}\text { travel time } \\
\text { velocity accuracy } \\
\text { velocity precision }\end{array}$ & $\begin{aligned} & 0.04 \mu \mathrm{s} \\
< & 2.0 \% \\
< & 0.5 \%\end{aligned}$ \\
\hline \multicolumn{2}{|l|}{ Post-Cruise Measurements (UCLA) } \\
\hline Minicores & \\
\hline $\begin{array}{l}\text { length } \\
\text { diameter } \\
\text { mass }\end{array}$ & $\begin{array}{l} \pm 0.008 \mathrm{~mm} \\
\pm 0.008 \mathrm{~mm} \\
\pm 1 \times 10^{-5} \mathrm{~g}\end{array}$ \\
\hline \multicolumn{2}{|l|}{ Grain Densities } \\
\hline (Archimedian method) & $<0.2 \%$ \\
\hline Bulk Density & $<0.3 \%$ \\
\hline \multicolumn{2}{|l|}{ Velocity } \\
\hline $\begin{array}{l}\text { travel time } \\
\text { velocity accuracy } \\
\text { velocity precision }\end{array}$ & $\begin{array}{l} \pm 0.008 \mu \mathrm{s} \\
<1.0 \% \\
<0.2 \%\end{array}$ \\
\hline
\end{tabular}

TABLE 3

Modal Analyses of Basaltic Rocks (vol. \%)

\begin{tabular}{|c|c|c|c|c|c|c|c|c|c|c|c|c|c|}
\hline 을 & ฮั & 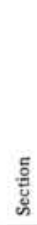 & : & 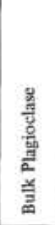 & 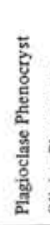 & 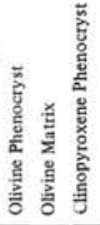 & 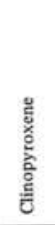 & gू & 츨 & 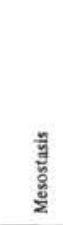 & 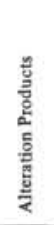 & $\frac{\stackrel{n}{0}}{\partial}$ & 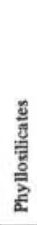 \\
\hline $\begin{array}{l}421 \\
421\end{array}$ & $\begin{array}{l}3 \\
3\end{array}$ & $\begin{array}{l}1 \\
1\end{array}$ & ${ }_{11}^{5}$ & $\begin{array}{l}43.8 \\
47.0\end{array}$ & & & $\begin{array}{l}34.8 \\
30.4\end{array}$ & & $\begin{array}{l}20.2 \\
20.1\end{array}$ & & $\begin{array}{l}1.5 \\
2.5\end{array}$ & & \\
\hline $\begin{array}{l}429 \mathrm{~A} \\
429 \mathrm{~A} \\
429 \mathrm{~A} \\
429 \mathrm{~A}\end{array}$ & $\begin{array}{l}1 \\
2 \\
2 \\
3\end{array}$ & $\begin{array}{l}1 \\
1 \\
1 \\
1\end{array}$ & $\begin{array}{c}3 \\
5 \mathrm{~b} \\
17 \\
7 \mathrm{~b}\end{array}$ & $\begin{array}{l}42.4 \\
47.8 \\
45.2 \\
42.8\end{array}$ & & $\begin{array}{l}-1.2- \\
-6.4^{-}\end{array}$ & $\begin{array}{l}35.2 \\
27.2 \\
32.6 \\
36.4\end{array}$ & $\begin{array}{l}4.6 \\
2.8 \\
6.2 \\
6.0\end{array}$ & $\begin{array}{r}8.0 \\
9.5 \\
10.2 \\
7.2\end{array}$ & & $\begin{array}{l}-10 \\
\overline{-6}^{5} \\
6.2\end{array}$ & $\begin{array}{l}4- \\
3- \\
8- \\
1.6\end{array}$ & \\
\hline $\begin{array}{l}425 \\
425 \\
425 \\
425\end{array}$ & $\begin{array}{l}7 \\
7 \\
7 \\
8\end{array}$ & $\begin{array}{l}1 \\
1 \\
2 \\
1\end{array}$ & $\begin{array}{l}7 \\
17 a \\
11 \\
16\end{array}$ & $\begin{array}{l}44.2 \\
41.7 \\
42.5 \\
41.6\end{array}$ & & 0.3 & $\begin{array}{l}38.7 \\
37.6 \\
46.4 \\
46.3\end{array}$ & $\begin{array}{l}7.4 \\
4.6\end{array}$ & $\begin{array}{r}8.7 \\
14.7 \\
6.2\end{array}$ & 5.5 & & $\begin{array}{l}1.0 \\
1.4\end{array}$ & $\begin{array}{l}5.5 \\
5.6\end{array}$ \\
\hline $\begin{array}{l}422 \\
422 \\
422 \\
422 \\
422\end{array}$ & $\begin{array}{l}7 \\
7 \\
8 \\
9 \\
9\end{array}$ & $\begin{array}{l}1 \\
2 \\
5 \\
3 \\
5\end{array}$ & $\begin{array}{c}7 \mathrm{e} \\
3 \\
14 \\
6 \mathrm{c} \\
6\end{array}$ & $\begin{array}{l}48.8 \\
30.3 \\
53.4 \\
52.6 \\
54.0\end{array}$ & $\begin{array}{l}t^{3} \\
t r \\
t r \\
t r \\
t r\end{array}$ & $\begin{array}{l}-\mathrm{tr}-\mathrm{tr} \\
-0.1- \\
-\mathrm{tr}- \\
-9.4- \\
\mathrm{tr} ?\end{array}$ & $\begin{array}{l}41.8 \\
48.9 \\
33.4 \\
34.4 \\
32.0\end{array}$ & $\begin{array}{l}3.3 \\
3.5 \\
\frac{5.3}{5.0} \\
5\end{array}$ & $\begin{array}{r}5.5 \\
17.0 \\
7.4 \\
8.8\end{array}$ & & & $\begin{array}{l}1.0 \\
0.4 \\
1.3\end{array}$ & \\
\hline $\begin{array}{l}428 \\
428 \mathrm{~A} \\
428 \mathrm{~A} \\
428 \mathrm{~A}\end{array}$ & $\begin{array}{l}6 \\
4 \\
7 \\
7\end{array}$ & $\begin{array}{l}1 \\
1 \\
1 \\
2\end{array}$ & $\begin{array}{r}8 \mathrm{c} \\
9 \mathrm{a} \\
2 \\
12\end{array}$ & $\begin{array}{l}48.0 \\
45.0 \\
55.4 \\
46.1\end{array}$ & & $-\mathrm{tr}-$ & $\begin{array}{l}28.1 \\
29.1 \\
27.4 \\
31.3\end{array}$ & $\begin{array}{l}7.7 \\
8.5 \\
6.9 \\
5.3\end{array}$ & & $\begin{array}{r}-14.3 \\
-16.9 \\
-10.3 \\
-17.3\end{array}$ & $\square$ & & \\
\hline $\begin{array}{l}427 \\
427 \\
427\end{array}$ & $\begin{array}{r}9 \\
9 \\
10\end{array}$ & $\begin{array}{l}1 \\
4 \\
4\end{array}$ & $\begin{array}{l}4 \\
6 \\
\text { le }\end{array}$ & $\begin{array}{l}16.1 \\
54.3 \\
56.4\end{array}$ & (glas & (ssy margin) & $\begin{array}{r}9.8 \\
33.4 \\
30.7\end{array}$ & $\begin{array}{l}-72 \\
7.1 \\
7.3\end{array}$ & $\begin{array}{r}2.2- \\
4.2 \\
2.2\end{array}$ & & $\begin{array}{l}1.0 \\
3.2\end{array}$ & 2.3 & \\
\hline $\begin{array}{l}424 \\
424 \\
424 \\
424 \\
424 B\end{array}$ & $\begin{array}{l}4 \\
5 \\
6 \\
6 \\
6\end{array}$ & $\begin{array}{l}6 \\
2 \\
1 \\
3 \\
1\end{array}$ & $\begin{array}{l}3 \\
2 b \\
5 \\
1 d \\
9\end{array}$ & $\begin{array}{l}40.7 \\
40.6 \\
40.7 \\
47.2 \\
36.1\end{array}$ & & $-0.3-$ & $\begin{array}{l}25.5 \\
38.0 \\
31.6 \\
28.4 \\
20.5\end{array}$ & $\begin{array}{r}11.9 \\
6.4 \\
10.2 \\
10.2 \\
-4\end{array}$ & $\begin{array}{l}22.2 \\
13.0 \\
17.7 \\
13.5 \\
.4-\end{array}$ & & 0.5 & $\begin{array}{l}0.2 \\
2.8\end{array}$ & \\
\hline
\end{tabular}


TABLE 4

Dry-Bulk Densities and Grain Densities over All Sites, Leg 54

\begin{tabular}{|c|c|c|c|c|}
\hline $\begin{array}{c}\text { Sample } \\
\text { (Interval in cm) }\end{array}$ & Piece & $\begin{array}{l}\text { Dry-Bulk } \\
\text { Density } \\
\left(\mathrm{g} / \mathrm{cm}^{3}\right)\end{array}$ & $\begin{array}{l}\text { Grain } \\
\text { Density } \\
\left(\mathrm{g} / \mathrm{cm}^{3}\right)\end{array}$ & Shipboard Visual Description \\
\hline \multicolumn{5}{|l|}{ EPR } \\
\hline $420-14-1,31-34$ & 5 & - & $2.9802^{a}$ & $\begin{array}{l}1-2 \% \text { plagioclase crystals, } 10-20 \% \\
\text { vesicles }\end{array}$ \\
\hline $421-3-1,79-82$ & 12 & - & $2.9873^{\mathrm{a}}$ & Aphyric, fine-grained \\
\hline $422-8-5,19-22$ & 3 & $2.8839^{\mathrm{a}}$ & $2.9661^{\mathrm{a}}$ & $\begin{array}{l}\text { Rare plagioclase phyric, fine- } \\
\text { grained }\end{array}$ \\
\hline $422-8-5,91-94$ & 10 & $2.8831^{\mathrm{a}}$ & $2.9931^{\mathrm{a}}$ & $\begin{array}{l}\text { graned } \\
\text { Sparsely plagioclase phyric, medium } \\
\text { coarse-grained } 2 \% \text { vesicles }\end{array}$ \\
\hline $\begin{array}{l}422-9-1,80-83 \\
422-9-2,44-47\end{array}$ & $\begin{array}{l}4 d \\
4 c\end{array}$ & $2.879^{b}$ & ${ }_{-}^{3.0306^{\mathrm{a}}}$ & $\begin{array}{l}\text { Coarse-grained aphyric } \\
\text { Fine-grained aphyric, vesicles }\end{array}$ \\
\hline \multicolumn{5}{|l|}{ GSC } \\
\hline $424-5-1,31-33$ & 5 & $2.845^{\mathrm{b}}$ & $3.001^{\mathrm{b}}$ & $\begin{array}{l}\text { Fine-grained, rare pinpoint vesicles } \\
\text { filled with green mineral }\end{array}$ \\
\hline $424-5-3,22-25$ & 2 & $2.886^{\mathrm{a}}$ & $2.9886^{\mathrm{a}}$ & Fine-grained, tiny sparse vesicles \\
\hline $424-6-1,29-32$ & 5 & $28804^{a}$ & $3.0015^{\mathrm{a}}$ & $\begin{array}{l}\text { Fine-grained basalt, rare pinpoint } \\
\text { vesicles }\end{array}$ \\
\hline $424-6-1,107-109$ & $10 \mathrm{c}$ & $2.872^{\mathrm{b}}$ & $3.060^{\mathrm{b}}$ & $\begin{array}{l}\text { Fine-grained, some less crystallized } \\
\text { parts, vugs }\end{array}$ \\
\hline $424 A-4-1,61-63$ & 8 & $2.8540^{\mathrm{a}}$ & $3.0778^{\mathrm{a}}$ & parts, vugs _ _ \\
\hline 424B-5-1, 27-30 & 4 & $2.8601^{\mathrm{a}}$ & $2.9996^{\mathrm{a}}$ & $\begin{array}{l}\text { Fine-grained, sparsely plagioclase } \\
\text { phyric, variolytic texture, filled } \\
\text { vesicles }\end{array}$ \\
\hline $424 \mathrm{~B}-5-1,139-141$ & 17 & $2.8598^{a}$ & $2.9482^{\mathrm{a}}$ & $\begin{array}{l}\text { Sparsely plagioclase phyric: } \\
\text { variolytic texture, filled tube } \\
\text { vesicles }\end{array}$ \\
\hline $424 \mathrm{~B}-6-1,65-68$ & 10 & $2.899^{\mathrm{b}}$ & $3.021^{\mathrm{b}}$ & Fine-grained, some vesicles and vugs \\
\hline $424 C-3-1,20-23$ & 2 & - & $2.9930^{\mathrm{a}}$ & $\begin{array}{l}\text { Fine-grained with rare microphenocrysts } \\
\text { vesicles and vugs }\end{array}$ \\
\hline $424 C-3-1,46-49$ & 4 & $2.889^{\mathrm{b}}$ & $3.003^{\mathrm{b}}$ & $\begin{array}{l}\text { Very fine-grained with few pinpoint } \\
\text { vesicles }\end{array}$ \\
\hline $425-7-1,130-133$ & $17 \mathrm{a}$ & $\begin{array}{l}2.7995^{\mathrm{b}} \\
2.7963^{\mathrm{a}}\end{array}$ & $\begin{array}{l}3.0285^{\mathrm{c}} \\
3.0569^{\mathrm{a}}\end{array}$ & Fine-grained clusters of vugs \\
\hline $425-7-2,115-117$ & 11 & $\begin{array}{l}2.880^{\mathrm{b}} \\
2.8950^{\mathrm{a}}\end{array}$ & $\begin{array}{l}3.0162^{\mathrm{c}} \\
3.0490^{\mathrm{a}}\end{array}$ & $\begin{array}{l}\text { Medium-grained plagioclase phyric } \\
\text { basalt ( } 2 \% \text { up to } 2 \mathrm{~mm} \text { crystals) }\end{array}$ \\
\hline $425-8-1,44-47$ & 6 & $2.7980^{\mathrm{b}}$ & $3.0115^{b}$ & $\begin{array}{l}\text { Coarse-grained, sparsely plagioclase } \\
\text { phyric, some weathering, blue } \\
\text { minerals in vesicles }\end{array}$ \\
\hline $425-8-1,70-73$ & 9 & $2.9040^{\mathrm{a}}$ & $2.9927^{\mathrm{a}}$ & $\begin{array}{l}\text { Coarse-grained, sparsely plagioclase } \\
\text { phyric }\end{array}$ \\
\hline $425-8-1,145-148$ & 16 & $2.9200^{\mathrm{b}}$ & $3.0265^{b}$ & $\begin{array}{l}\text { Plagioclase and cpx porphyritic } \\
\text { crystals up to } 3 \mathrm{~mm}\end{array}$ \\
\hline $425-9-3,69-72$ & 10 & - & $2.9873^{\mathrm{a}}$ & $\begin{array}{l}\text { Plagioclase phyric without glass or } \\
\text { grain size variation, coarse-grained }\end{array}$ \\
\hline \multicolumn{5}{|c|}{ Siqueiros Fracture Zone } \\
\hline $427-9-1,11-13$ & 2 & - & $2.9777^{\mathrm{a}}$ & Very fine-grained basalt \\
\hline $427-9-3,62-65$ & $5 \mathrm{~b}$ & - & $2.9853^{\mathrm{a}}$ & $\begin{array}{l}\text { Medium-grained, aphyric, vesicles } \\
\text { are rare, rock is fresh }\end{array}$ \\
\hline $427-9-4,132-135$ & 6 & - & $2.9919^{a}$ & $\begin{array}{l}\text { Medium-grained, sparsely plagioclase } \\
\text { and cpx phyric; massive non-vesiculat }\end{array}$ \\
\hline $427-10-4,74-77$ & $1 \mathrm{~g}$ & - & $3.0243^{2}$ & $\begin{array}{l}\text { Aphyric medium-grained basalt; } \\
\text { Section } 10-4 \text { is one continuously } \\
\text { cored unit }\end{array}$ \\
\hline \multicolumn{5}{|l|}{ EPR } \\
\hline $428-5 \cdot 4,35-38$ & 4 & $2.873^{\mathrm{a}}$ & $2.9471^{\mathrm{a}}$ & $\begin{array}{l}\text { Fine-grained basalt with rare pinpoint } \\
\text { vesicles }\end{array}$ \\
\hline $428-6-1,87-90$ & $8 \mathrm{e}$ & - & $2.9328^{\mathrm{a}}$ & $\begin{array}{l}\text { Medium-grained with very sparse } \\
\text { pinpoint vesicles }\end{array}$ \\
\hline $428-6-1,121-124$ & $10 \mathrm{~b}$ & - & $2.9835^{3}$ & $\begin{array}{l}\text { Fine-grained, aphyric, rare empty } \\
\text { vesicles }\end{array}$ \\
\hline $428-6-2,73-76$ & 8 & - & $2.9171^{\mathrm{a}}$ & $\begin{array}{l}\text { Massive, non-vesicular, aphyric } \\
\text { medium-grained }\end{array}$ \\
\hline $428 \mathrm{~A}-4-2,116-119$ & 8 & - & $2.9699^{3}$ & Aphyric plagioclase-pyroxene basalt \\
\hline $428 \mathrm{~A}-5-2,101-104$ & se & - & $3.0100^{\mathrm{a}}$ & Medium-grianed oxidized aphyric \\
\hline $429 \mathrm{~A}-2-1,14-17$ & 3 & $2.7315^{\mathrm{a}}$ & $3.0055^{\mathrm{a}}$ & Fine-grained, aphyric, glassy edges \\
\hline $429 A-2-1,53-56$ & 7 & $2.7227^{\mathrm{a}}$ & $2.9615^{\mathrm{a}}$ & Fine-grained, aphyric, glassy edges \\
\hline $429 \mathrm{~A}-3-1,103-106$ & 5 & $2.7920^{\mathrm{a}}$ & $2.9717^{3}$ & Slightly coarse-grained, a phyric \\
\hline
\end{tabular}

shown to hold for rock types ranging from soft sediments to ultramafic rocks. Considerable work has been done on establishing the theoretical basis of the relationship, usually assuming solid-state models for the material (Anderson, 1972). The formulations depend on atomic properties and involve the mean atomic volume of atomic pairs. This subject is beyond the scope of this paper and we need to note here only that the mathematical expression of this relationship is:
TABLE 5

Grain Density Averages, Leg 54

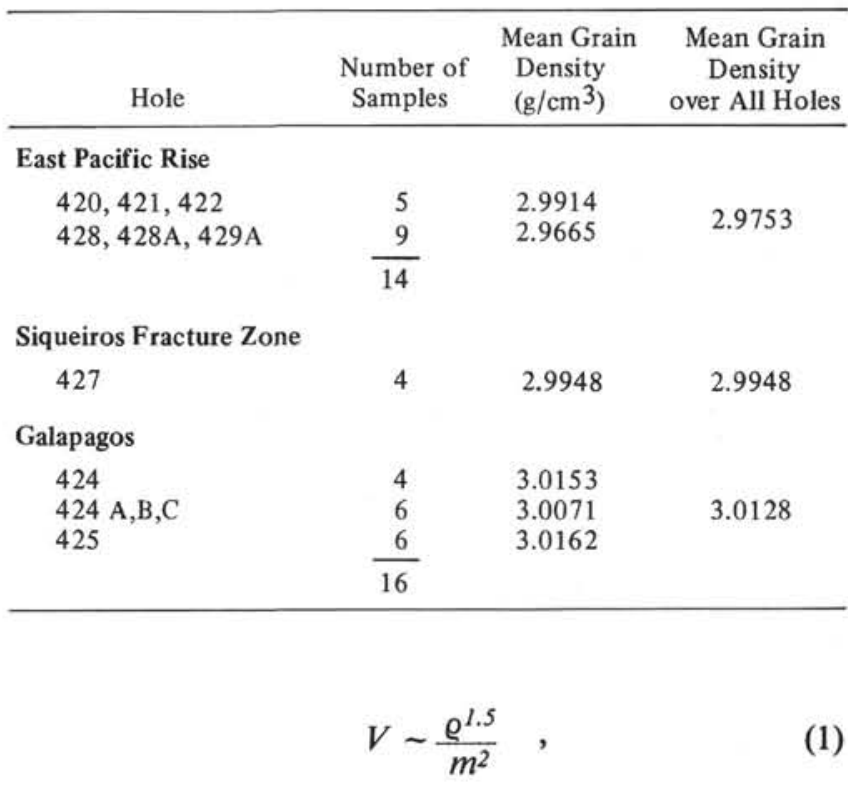

where $V$ is velocity, $\varrho$ is density, and $m$ is the mean atomic weight. For most silicates, $m$ is about 21 and essentially a constant. For the range of densities observed in most silicate rocks, we cannot empirically distinguish a power law in density from a linear law. The above relationship seems to hold whether density changes are mainly due to mineralogy, pressure, temperature, the degree of glassiness or crystallinity of the rock, or even porosity (i.e., vesicles). However, more complicated rock textures can greatly perturb these systematics. In particular, the occurrence of very fine microcracks has virtually no effect on bulk density, but it has a significant effect on velocity at low pressures (Walsh, 1965; Warren, 1977). Extreme examples of this effect are given by lunar rocks, which fall far from the Birch law (Schreiber and Anderson, 1970). At hydrostatic pressures high enough to close such cracks, data fall relatively close to the Birch law. Compressional velocity is also affected by saturation of the cracks by a fluid. If cracks are saturated, then they are (loosely speaking) partly pinned by the fluid; and even at low pressures (such as used in the shipboard measurements here) compressional velocity data for a saturated sample may show a more definite correlation to density than do data for dry samples.

Therefore, the main variables governing velocitydensity systematics in a rock are: (1) original mineralogy and chemical composition, (2) thermodynamic conditions under which the measurements are made, (3) petrographic texture and the degree of crystallinity or glassiness and (4) primary porosity (vugs and pores), and microfractures that occur in the rock. The effects of any one of these variables may mask the effect of the others. Nonetheless, some measure of these effects may be real- 
ized in plots of velocity versus density, and similarity of trends in two or more sets of data can suggest a commonality in cause.

\section{Birch Systematics by Site Groupings}

\section{Normal Fabric Sites}

Sites 421,423 , and 429 are located on what is termed normal EPR fabric. All samples from these sites appear to be pieces of highly jointed, very thin tabular flows or oblate pillows, which have been subjected to intense mechanical fragmentation. The samples consist of both glassy and fine-grained specimens. Those from Sites 421 and 423 are olivine-free, while the Site 429 samples are both olivine-free and olivine-bearing.

The density-velocity data for the normal fabric samples fall within a fairly well-defined elongate band, designated field 1 in Figure 2 . The trend seems to be controlled by variations in density at constant mean atomic weight. The density variations, in turn, are mainly governed by the degree of glassiness or vugginess of the samples, as opposed to mineralogy or degree of microfracturing. Indeed, there appears to be surprisingly little microfracturing of these samples in spite of the intense megascopic fragmentation to which these basalts apparently have been subjected. This suggests to us that the primary fragmentation occurs on the scale of faults, joints, and fissures, and is not directly controlled by mineralogy or petrography.

\section{Site $\mathbf{4 2 5}$}

This site, located north of the Galapagos spreading axis and on a local heat flow maximum, contained eight petrographic units corresponding to several distinct cooling units. There is also the possibility that three of the units are intrusive, and at least they can be described as dolerite. Most of the samples are pyroxene-plagioclase-(olivine) phyric or sparsely phyric basalt to dolerite. Alteration is generally more variable here than elsewhere, and there is some indication of hydrothermal activity at this site.

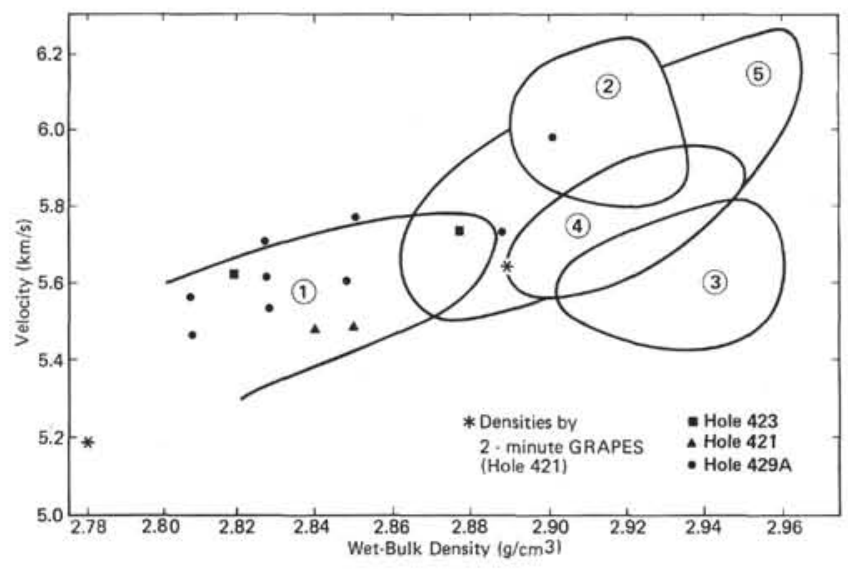

Figure 2. Velocity versus wet-bulk density for sites on normal fabric of the East Pacific: Field 1 is defined by the samples from Holes 421 and 423 .
The $V_{p}-\varrho$ plot for the Site 425 samples (Figure 3) defines an elongate band which falls along the trend of the normal fabric samples from the EPR (Figure 2). This suggests that the degree of glassiness (or crystallinity) also controls the $V_{p}-\varrho$ relations at Site 425 . All seven data points in the upper right-hand corner of field 5 represent doleritic specimens. The overlap between basalt and dolerite occurs at $\varrho=2.90-2.92 \mathrm{~g} / \mathrm{cm}^{3}$, and it is not surprising that specimens falling within this interval caused the most difficulty with respect to their correct naming (basalt or dolerite).

\section{Sites 422 and $\mathbf{4 2 8}$}

Site 422 was located in a "moat" surrounding the OCP ridge, clearly off the normal EPR fabric. Holes 428 and $428 \mathrm{~A}$ were drilled south of the OCP ridge in an area marking the transition from normal fabric to transverse ridge structure. Both the physical property data and the lithologic and petrographic studies indicate an affinity between the doleritic units of these two sites.

The rocks at Site 422 consist of two units of coarsegrained dolerite (meaning here a relatively coarsegrained rock of basaltic composition which may or may not be intrusive), underlain by glassy basalt (one sample). The rocks are very fresh and obviously have a high degree of crystallinity. Those at Site 428 (and the uppermost section of Hole 428A) consist of flows of cryptocrystalline olivine-bearing basalt. The bottom portion of Hole 428A consists of a sequence of medium-grained, olivine-free dolerites. Although alteration is generally minor, the doleritic rocks have narrow zones of intense alteration along margins and cracks.

In Figure 4 it can be seen that the data for Site 422 group fairly tightly around a velocity of $6 \mathrm{~km} / \mathrm{s}$ and a $\varrho$ of $2.92 \mathrm{~g} / \mathrm{cm}^{3}$ (field 2). The data for Site 428 (Figure 5) form a broad band, which terminates in and near field 2. However, the data for the olivine-bearing basalts completely overlap those for the doleritic unit. The fresh cryptocrystalline olivine basalts cannot be resolved from the medium-grained doleritic rocks of either Hole 422 or Hole $428 \mathrm{~A}$ on the basis of $V_{p}-\varrho$ plots alone. The data shown in Figure 5 also appear to form a steeper average trend than that of the normal fabric sites, which

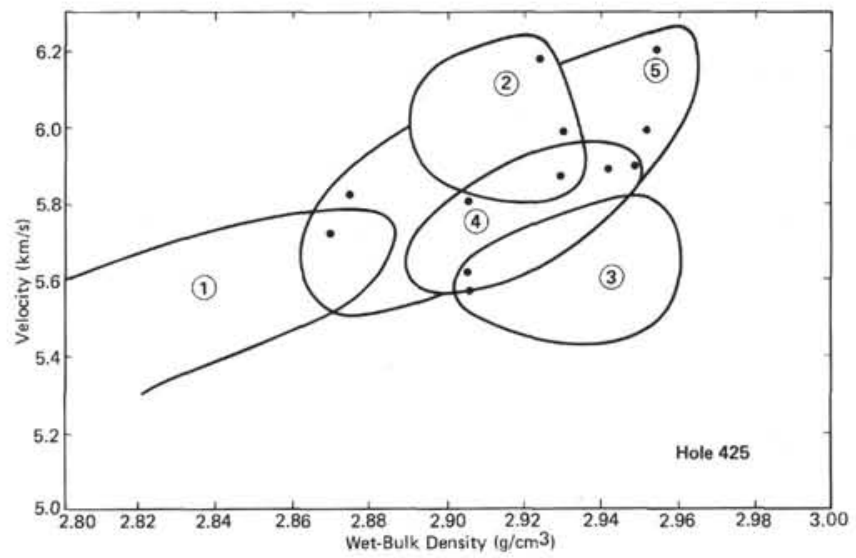

Figure 3. Velocity versus wet-bulk density for Hole 425, in the Galapagos, north of the spreading axis. 


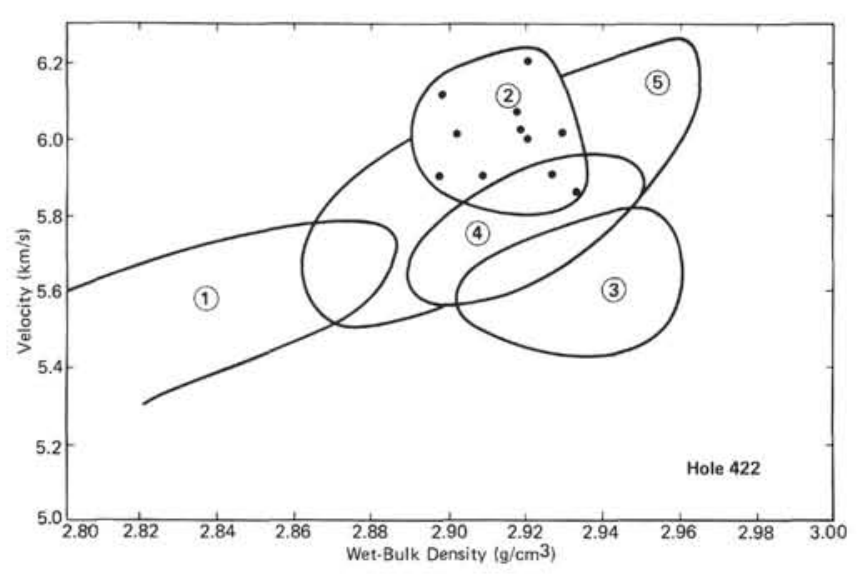

Figure 4. Velocity versus wet-bulk density for Hole 422, at the $O C P$ ridge.

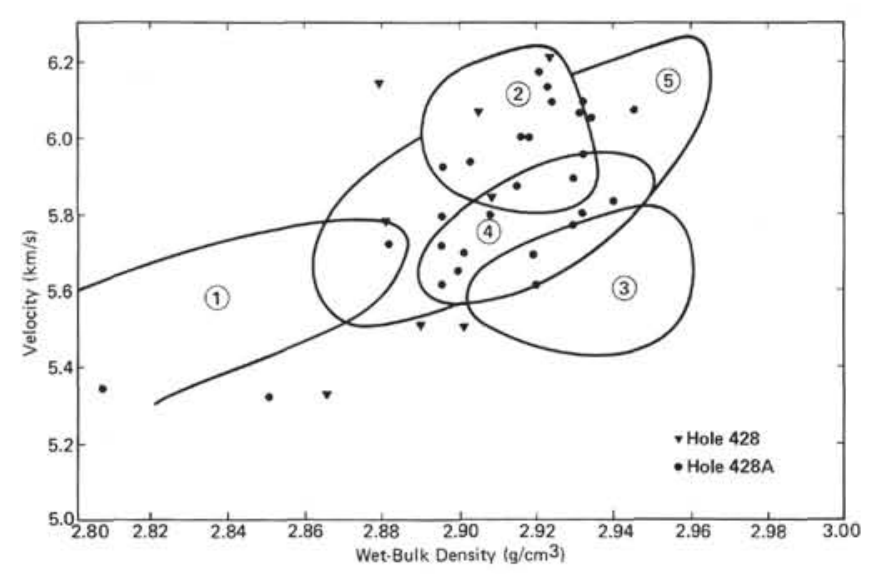

Figure 5. Velocity versus wet-bulk density for Holes 428 and $428 \mathrm{~A}$, located just south of the OCP ridge.

is probably a consequence of slight microfracturing and alteration in combination with the wide variation in the plagioclase-clinopyroxene ratios of these rocks.

Taken on the whole, Holes 421, 423, 429A, 425, 422, 428 , and $428 \mathrm{~A}$ (fields 1,2 , and 5 ) define a broad band controlled mainly by degree of glassiness within a roughly similar mineralogic suite (Table 3 ). The normal fabric rocks are the least crystalline and comprise the lower portions of the band. The higher portions are made up of data from more crystalline and/or doleritic flow units, and of more olivine-rich samples. There is no strong correlation with grain size.

\section{Site 424 (Galapagos Mounds Area)}

The sequence of holes on this site were drilled across the hydrothermal mounds area south of the GSC. Holes 424 and $424 \mathrm{~A}$ were located on individual mounds, Holes $424 B$ and $424 C$ between mound chains. Generally, the basalts from these holes are fine-grained, aphyric to sparsely plagioclase phyric rocks with few glassy margins and about 1 to 3 per cent vesicles. Cooling units usually had to be identified on the basis of crystal size versus depth curves.
The $V_{p}-\varrho$ data for the basalts from these holes are shown in Figure 6 . The Hole 424 data define a roughly circular pattern that lies mainly below field 5 . Hence, these samples show a distinctly lower $V_{p}$ than other specimens with similar density. Depending upon one's viewpoint, these samples have either an anomalously low velocity or anomalously high density compared to the $V_{p}-\varrho$ trend defined by fields $1,2,5$, and perhaps 4 . The data from Holes 424A, B, and C are also somewhat anomalous in this same respect, falling in the lower half of field 5 (Figure 6). It will be shown later that these anomalously low velocities at specified densities are probably caused by iron enrichment.

\section{Site $\mathbf{4 2 7}$}

This site was chosen to provide a stratigraphic sampling of one of the deep, flat-floored troughs that occur within the Siqueiros fracture zone transform fault. A single, remarkably uniform flow of massive, mediumgrained, sparsely plagioclase phyric basalt was drilled. Horizontal jointing is pronounced; holocrystalline, intergranular textures prevail in the central part of the unit, and a few of the cores showed large tubular vesicles and irregular vugs. Traces of hydrothermal alteration may occur in part of the unit.

As might be expected, the velocity-profile data are very tightly correlated with the flow structure; and the $V_{p}-\varrho$ data form a very tight cluster, which is virtually coincident with the field defined by the data from Holes $424 \mathrm{~A}, \mathrm{~B}$, and C (Figures 7 and 8 ). The data from this site also fall within the lower portion of field 5 (Site 425). These relationships suggest to us that Site 427 shows a closer affinity to the Galapagos sites than to the other EPR sites (at least from the standpoint of physical properties). It will be shown that this affinity is, in fact, a chemical one involving iron enrichment.

\section{Comparison With MAR Basalts}

Figure 9 shows a plot of all Leg 54 shipboard data. The two lower straight lines represent linear regression fits for the data from Holes 421, 423, 429A, and 425 .

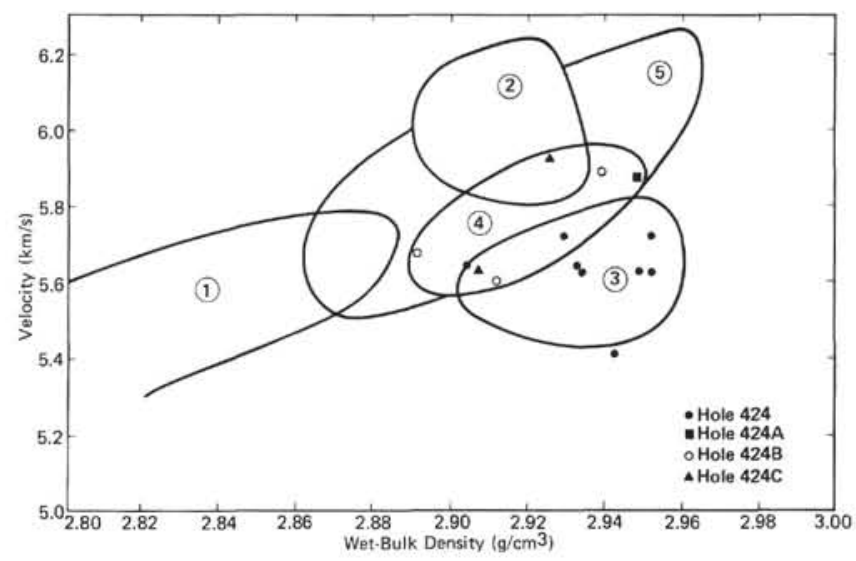

Figure 6. Velocity versus wet-bulk density for samples from the Mounds Hydrothermal area in the Galapagos. 


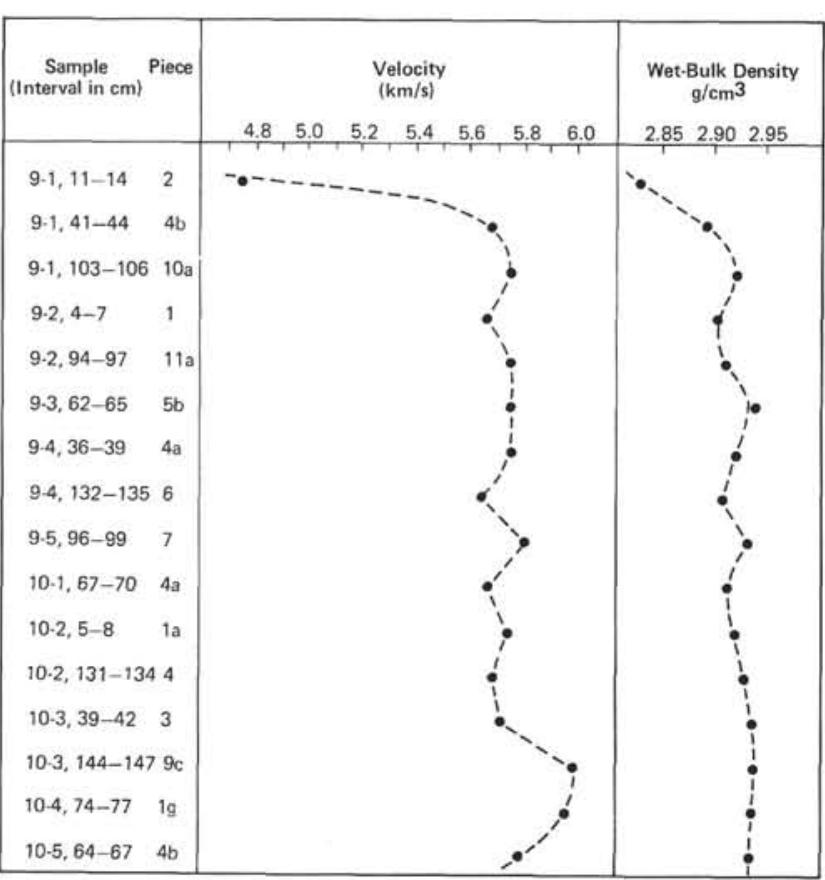

Figure 7. Velocity and density profile for the massive flow unit at Hole 427 in the Siqueiros fracture zone.

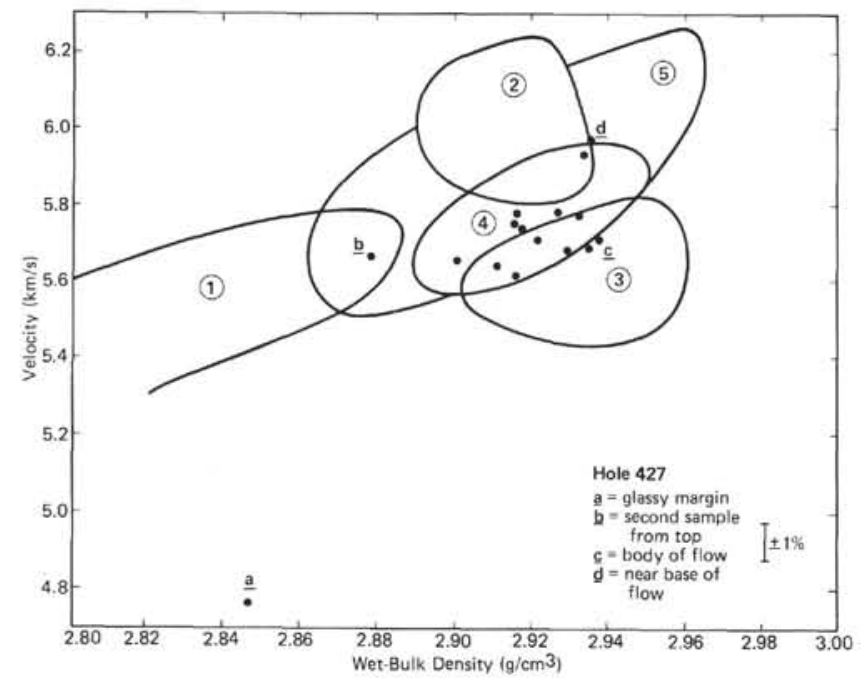

Figure 8. Velocity versus wet-bulk density for samples of the massive flow unit, Hole 427 in the Siqueiros fracture zone.

The slopes and intercepts of the lines are $m=3.6875, b$ $=-4.880$ for $V_{p}$ on $\varrho$; and $m=5.3298, b=-0.603$ for $\varrho$ on $V_{p}$. The slopes are remarkably parallel to both the Birch law relationship and the trend of the MidAtlantic Ridge (MAR) dredge samples measured by Christensen and Shaw (1970). The similarity in the slopes of our regression fits to the Birch law relationship substantiates the statement that the Leg 54 rocks are relatively devoid of microfracturing. A similar statement apparently applies to the youthful MAR rocks as well.
The main differences shown in Figure 9 pertain to the intercepts and offsets between our regression lines and the Birch law and MAR trends. Qualitatively, this is not surprising since our results were obtained at atmospheric pressure, and the Birch law and Christensen and Shaw data were obtained at $10 \mathrm{kbar}$. Figure 10 shows $V_{p}-\varrho$ measurements for some of our samples at both atmospheric pressure and $3 \mathrm{kbar}$ in comparison to data taken at 2-10 kbar for other Pacific Layer 2 basalts (Christensen and Salisbury, 1973). The fact that our data points fall largely within the range of the data at 2-10 kbar indicates that the intercept and offset differences are at least partly due to the experimental differences. Whether or not second-order $V_{p}-\varrho$ differences exist between Pacific and Atlantic basalts cannot be determined with our present data base.

\section{Extrapolation to In Situ Conditions}

In any laboratory study of a rock's physical properties, there is always some question about the representativeness of one's results for true in situ values. Such uncertainty casts even more doubt upon the correlation of one's measurements to analogous properties obtained by remote sensing techniques.

It is generally assumed that oceanic crustal rocks, even those at the top of Layer 2, are under a hydrostatic load corresponding to the hydrostatic head of the ocean. At face value, then, our study would appear to be particularly open to criticism because our measurements (and subsequent velocity-density systematics) were made mainly under atmospheric pressure conditions. Although this makes comparisons with other reported Birch systematics difficult, it was not an over-

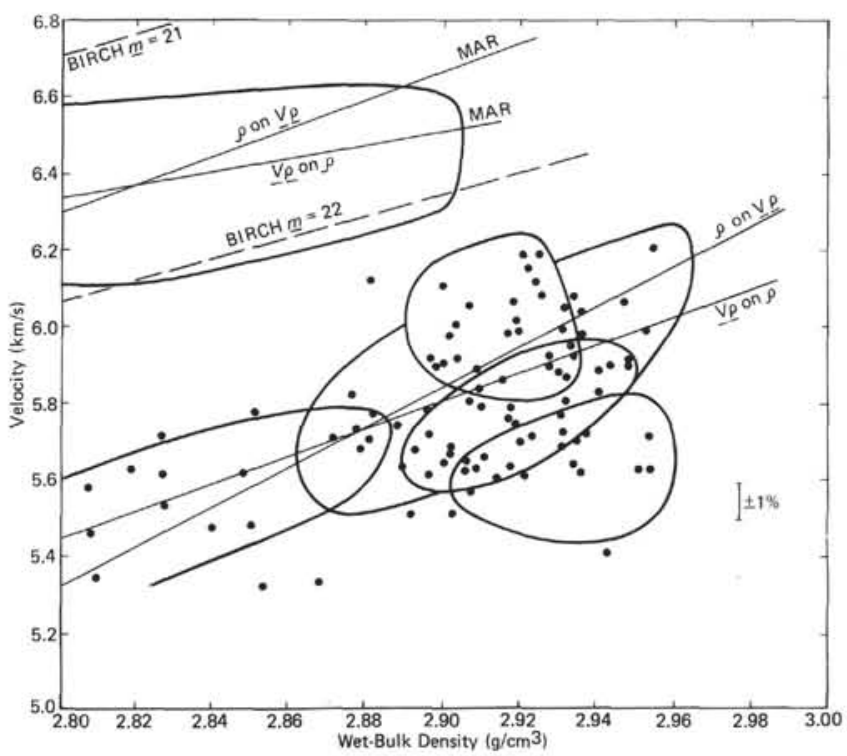

Figure 9. Velocity versus wet-bulk density for all shipboard data. The lines marked Birch 21 and 22 are Birch curves for rocks of atomic weight 21 and 22. The outlined field, and regression relations marked MAR (10 kbar) are for data from the Mid-Atlantic Ridge (Christensen and Salisbury, 1973). 


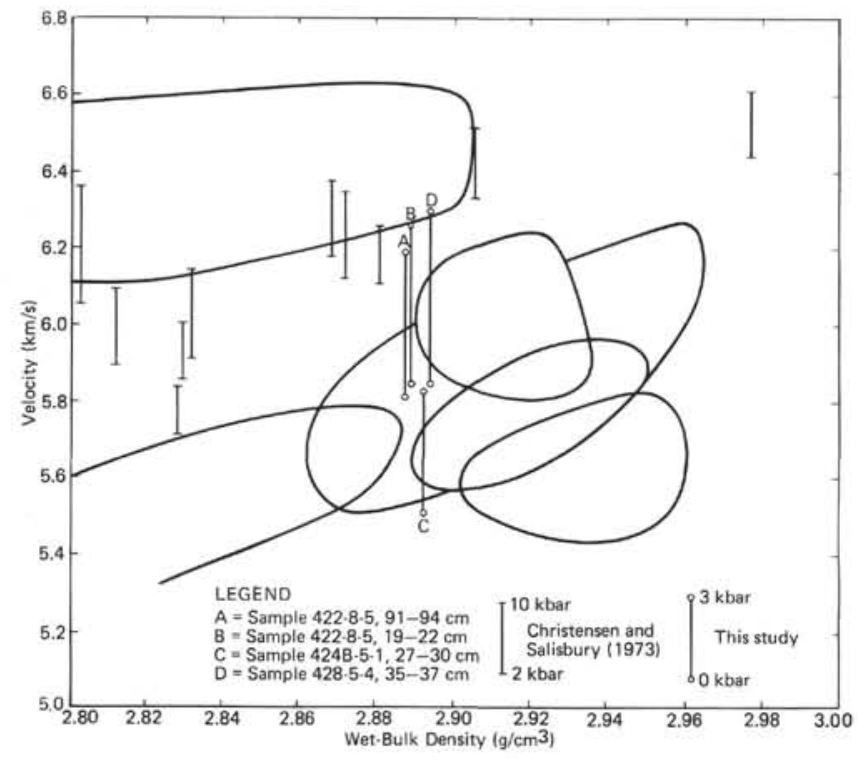

Figure 10. The effect of pressure on velocity. The outlined fields are the same as those in Figure 9. The barred lines show the increase in velocity between 2 $k b a r$ and 10 kbar for samples from the Mid-Atlantic Ridge. The vertical lines ending in circles show the increase in velocity from 0 kbar to 3 kbar for samples in this study.

sight or equipment shortcoming on our part but a purposeful tactic to produce more realistic approximations to in situ conditions. We contend that the effective pressures acting on sea-floor basalts are very low (and much less than hydrostatic pressure), because the rocks are essentially saturated with sea water. Hydrostatic pressure thus acts not just on the outer surfaces of the rock but also on pore surfaces within the rock.

This suggestion can be tested by using measured density data. From the dry-bulk densities and the wholerock matrix densities, the predicted densities of the saturated samples can be easily calculated and compared with those measured aboard ship on the saturated samples. A comparison of predicted wet-bulk density to measured wet-bulk density for seven samples is given in Table 6. The predicted wet density is calculated from grain and dry-bulk densities which were measured independently of each other (at UCLA). The measured wetbulk densities are shipboard data, obtained on minicores using a pan balance. The general agreement between the measured and calculated wet-bulk densities implies that almost all the pores are interconnected, can be drained by drying and, conversely, were completely saturated under in situ conditions. Grain densities were also calculated aboard ship for some samples using their wet- and dry-bulk densities and assuming total saturation. For two samples from Site 425, these values could be compared to the measured laboratory (pycnometer) grain densities (Table 4); they agree to within 1 per cent.

\section{Comparison of Laboratory Results With Seismic Velocities}

It has been observed that laboratory measurements of velocities in sea-floor basalts are often significantly higher than those measured with seismic techniques, at least in those instances where reliable velocities were obtained in the upper few hundred meters of Layer 2. One explanation for this discrepancy in youthful (i.e., unaltered) basalts is that seismic velocities, which represent averages obtained over hundreds to thousands of meters, are lowered by the presence of faults, fractures, and fissures. Another contributing cause of the difference may relate to our preceding discussion - that the laboratory measurements were made under confining pressures that were too high. Where such a situation applies, it could account for as much as $0.2 \mathrm{~km} / \mathrm{s}$ of difference if average sea floor pressures were used and up to $1.0 \mathrm{~km} / \mathrm{s}$ at higher confining pressures.

In the EPR region drilled on Leg 54, the differences between our measured velocities and those reported for the uppermost crust by Orcutt et al. (1976) and by Rosendahl and Dorman (this volume) from seismic refraction analyses average about $2.2 \mathrm{~km} / \mathrm{s}$ for all off-ridge localities (e.g., compare fig. 9 with fig. 5 in Orcutt et al., 1976). The precision of Orcutt et al.'s values in the uppermost crust is admittedly open to question, but there

TABLE 6

Test of Pore Connectiveness by Comparison of Measured and

Predicted Wet-Bulk Densities for Basalts From Leg 54

\begin{tabular}{lccccccc}
\hline $\begin{array}{c}\text { Sample } \\
\text { (Interval in cm) }\end{array}$ & Piece & $\begin{array}{l}\text { Dry-Bulk }^{\mathrm{a}} \\
\text { Density } \\
\left(\mathrm{g} / \mathrm{cm}^{3}\right)\end{array}$ & $\begin{array}{l}\text { Matrix }^{\mathrm{b}} \\
\text { Density } \\
\left(\mathrm{g} / \mathrm{cm}^{3}\right)\end{array}$ & $\begin{array}{l}\text { Porosity } \\
(\%)\end{array}$ & $\begin{array}{l}\text { Predicted }^{\mathrm{c}} \\
\text { Wet-Bulk } \\
\left(\mathrm{g} / \mathrm{cm}^{3}\right)\end{array}$ & $\begin{array}{l}\text { Measured } \\
\text { Wet-Bulk } \\
\left(\mathrm{g} / \mathrm{cm}^{3}\right)\end{array}$ & $\begin{array}{c}\Delta \\
(\%)\end{array}$ \\
\hline $424-5-3,22-25$ & 2 & 2.8886 & 2.9886 & 3.35 & 2.923 & 2.936 & -0.44 \\
$424-6-1,29-32$ & 5 & 2.8804 & 3.0015 & 4.03 & 2.922 & 2.954 & -1.08 \\
$424 \mathrm{~B}-5-1,139-144$ & 17 & 2.8598 & 2.9482 & 3.00 & 2.890 & 2.913 & -0.79 \\
$425-7-1,130-133$ & $17 \mathrm{a}$ & 2.7963 & 3.0569 & 8.52 & 2.884 & 2.877 & +0.24 \\
$425-7-2,115-118$ & 11 & 2.8950 & 3.0490 & 5.05 & 2.947 & 2.926 & +0.72 \\
$425-8-1,70-73$ & 9 & 2.9040 & 2.9927 & 2.96 & 2.934 & 2.954 & -0.68 \\
429 A-3-1, 103-106 & 5 & 2.7920 & 2.9717 & 6.05 & 2.854 & 2.889 & -1.21 \\
\hline
\end{tabular}

aLaboratory measurement by weight and length on ground core.

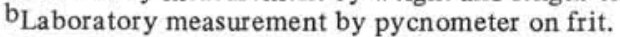

${ }^{c}$ Calculated from laboratory data.

dShipboard measurement by weight and length on minicore. 
is little doubt that the difference here is both real and sizable.

This discrepancy cannot be accounted for on the basis of incorrectly assumed in situ pressure and must be a consequence of the fractured state of lthe EPR fabric basalts. We have shown earlier that the degree of microfracturing in the EPR basalts is relatively low, which leads us to conclude that the fracturing must occur mainly on a megascopic scale.

In order to produce seismic velocities that are more than $2 \mathrm{~km} / \mathrm{s}$ lower than laboratory velocities, the basalt flows must be highly disrupted. A high estimate of the porosity associated with this rupture can be made by using the recursive fit of $V_{p}-\varrho$ from Figure 9 . This gives a porosity of 15 per cent to 20 per cent. Such an estimate assumes considerable vugginess and granularity in the fractured flows.

However, this disruption is more likely caused by joints and narrow cracks which have minimum spacings on the order of meters (or of at least decimeters). The effective fabric properties for this type of model can be calculated assuming fracture dimensions (Warren and Nashner, 1976; O'Connell and Budianski, 1974). For such models only a few per cent of such fracture basalt is required.

It is clear that the extreme drilling difficulties encountered on Leg 54 relate mainly to the mechanical state of the EPR fabric.

In the same vein, it is interesting that the difference between laboratory and seismic velocities in the axial block region of the EPR is only about $0.5 \mathrm{~km} / \mathrm{s}$, which is well within the precision of the uppermost crustal velocities reported by Orcutt et al. (1976) and also within the velocity range we find in our laboratory specimens. We take this to mean that the axial block basalts are relatively unfractured and that fragmentation of the sea floor occurs at the margins of the axial block, probably as slivers of crust spall off the margins and become incorporated into the normal fabric. We find it more than a little ironic that the place where a deep penetration hole is most feasible in the $9^{\circ} \mathrm{N}$ area of the EPR is also the place where lack of sediments precludes drilling.

The situation of the GSC is less certain, because the refraction data are still being analyzed. However, it appears that very low uppermost crustal velocities (e.g., $3.5-4.0 \mathrm{~km} / \mathrm{s}$ ) are observed here both at the ridge axis and along the off-ridge shooting lines (Bibee, personal communication). This suggests that sea floor fragmentation is also severe in the Galapagos region and that it occurs very soon after the formation of the sea floor. The probable loci of this fragmentation are along the faults that isolate and define the axial rift.

Assuming that the above analysis is correct-and we believe it is-then severe drilling difficulties should be expected wherever reliable seismic refraction velocities are significantly lower than the measured velocities in equivalent rocks. Numerical equivalence of the two kinds of measurements will occur only where fragmentation is minor or where fractures become infilled and cemented with secondary minerals. In the former case the in situ velocities will be similar to competent rock velocities; in the latter, both sample and in situ velocities will converge to an intermediate value. Exactly where cementation becomes effective in the eastern Pacific is far from certain, but it clearly does not occur within the first $5 \mathrm{~m}$.y. of crustal evolution in the $9^{\circ} \mathrm{N}$ area of the EPR, and probably not within the first $20 \mathrm{~m}$.y. The convergence value is equally uncertain and probably variable because it depends upon the original degree of fracturing, the velocity of the cementing materials, the degree of alteration, and the velocity of the basaltic portion of the rock. However, for velocity differentials of $1.5-2.5 \mathrm{~km} / \mathrm{s}$, laboratory velocities of $5.9 \mathrm{~km} / \mathrm{s}$, and a calcite cement, the convergence velocity would range from 4.6 to $5.2 \mathrm{~km} / \mathrm{s}$.

\section{THE IRON EFFECT}

In the preceding discussions of Birch systematics at Sites 424 and 427 we alluded to a chemical control, specifically iron enrichment. The way in which iron influences these systematics is, of course, by its effect on mean atomic weight (see equation 1). Hence, given two otherwise identical rocks which have identical bulk densities, the more iron-rich rock will have the lower velocity.

There is a good first-order correlation between iron enrichment and velocity in the Leg 54 samples. Figure 11 shows a plot of grain density, total iron (\%), and all velocity data for those samples which have densities higher than $2.90 \mathrm{~g} / \mathrm{cm}^{3}$. Site 424 (Galapagos Mounds area) yields the highest iron contents, lowest mean velocities, and most of the higher mineral densities. Site 427 , in the Siqueiros fracture zone, is intermediate in all three of these parameters, while the PT-4 EPR samples (Sites 429, 428, 422, and 423) include those with the least iron, highest mean velocities, and lowest mean matrix densities. It is interesting that the data for Site 425 , a Galapagos site, are clearly distinguished from the Site 424 data, both in measured $\mathrm{Fe}_{2} \mathrm{O}_{3}$ and velocity. (There are insufficient grain density data to establish further correlation). The data for the OCP Ridge moat sites (Holes 422, 428 and 428A) also group fairly tightly both in iron content and in velocity.

The measured variation in iron can be used to predict variation in matrix densities. If a typical grain density of the PT- 4 basalts is taken to be $2.97 \mathrm{~g} / \mathrm{cm}^{3}$, then a 5 per cent iron enrichment predicts $\varrho=3.08$ for the Galapagos basalts. At constant density the effect on velocity can also be predicted. The more iron-rich rock should have a lower velocity by about 5 per cent. The spread in velocity from the Site 422 average to that of Site 424 is about 8 per cent, so the predicted and observed spreads are in reasonable agreement.

\section{CONCLUSIONS}

Velocity-density systematics for Leg 54 basaltic rocks are controlled by a combination of the degree of crystallinity or glassiness, microstructure, and original mineralogy and chemistry, but the relative importance of these factors varies between and among certain site groupings. Degree of crystallinity is an important in- 

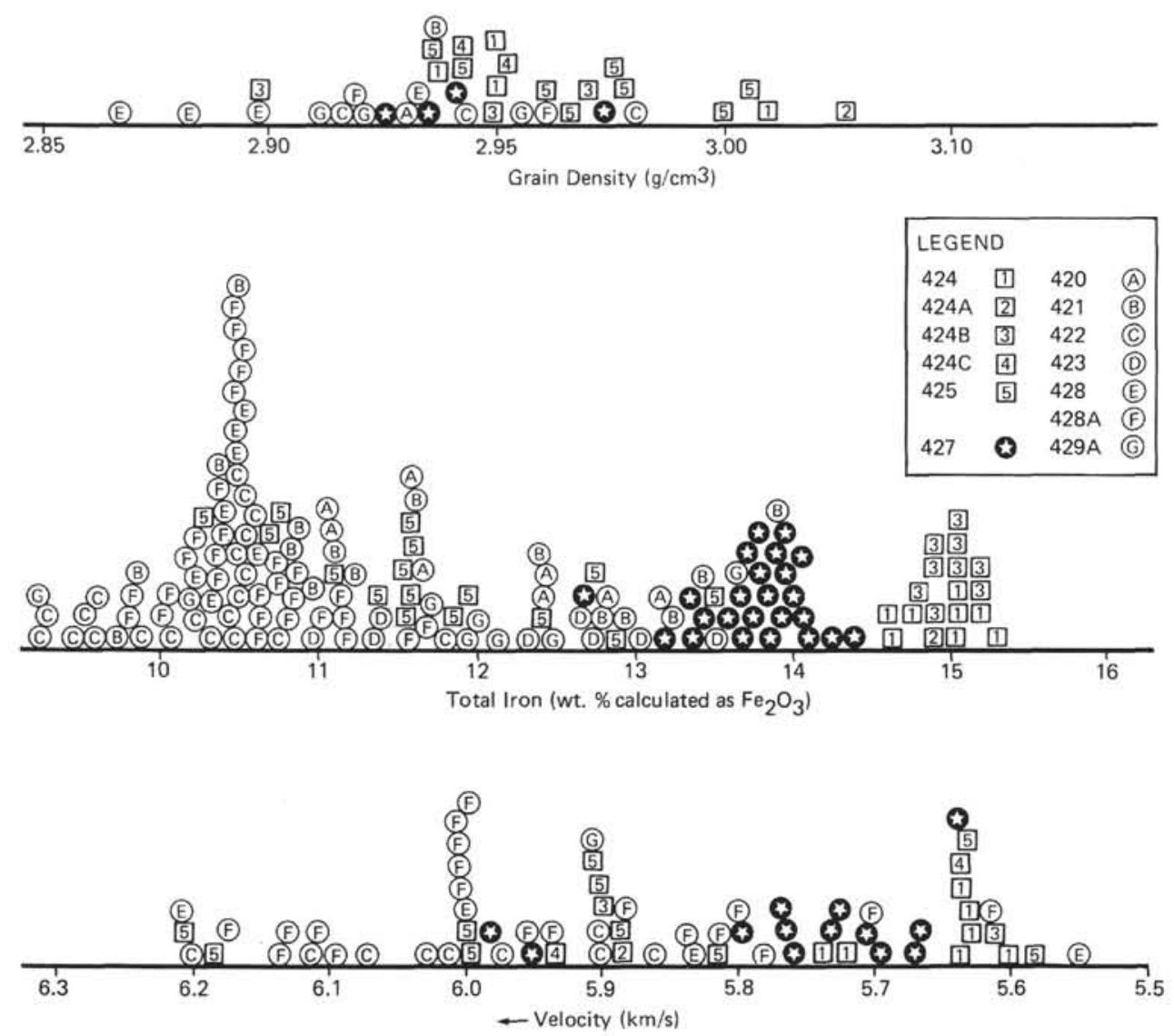

Figure 11. Grain density, total iron (percentage), and velocity of Leg 54 samples. The velocity data are from this paper, for samples with densitites above $2.90 \mathrm{~g} / \mathrm{cm}^{3}$. Total iron content is from XRF measurement, and the grain densities are from Table 4.

fluence everywhere and appears to be the main control on $V_{p}-\varrho$ relationships at the EPR normal fabric sites (Sites 421, 423, and 429), the OCP moat sites (Sites 422 and 428), and at Galapagos Site 425. The effect of microstructure such as cracks is relatively minor within these site groupings but may account for the difference in trend between the normal fabric and OCP moat sites. Original mineralogy is, of course, always an important factor but a difficult one to isolate. Its effects are most noticeable at the OCP moat sites, where the plagioclase: clinopyroxene ratios are quite variable. Original chemistry, in this case relative enrichment in iron, is the most difficult factor of all to evaluate. Nonetheless, we have been able to demonstrate that iron enrichment produces anomalously low measured velocities at densities above about $2.90 \mathrm{~g} / \mathrm{cm}^{3}$, and we cite the $V_{p}-\varrho$ relationship at Sites 424 and 427 as an example of this effect.

We also have demonstrated that the effective in situ pressure acting on Leg 54 basalts is considerably less than the simple hydrostatic load and perhaps close to zero. This suggests that measurements of physical properties at elevated pressures may produce erroneously high in situ values. However, because most of our measurements were made at atmospheric pressure, this effect cannot account for the $2.5 \mathrm{~km} / \mathrm{s}$ velocity differential observed between our EPR measurements and the seismic refraction results. The very low seismic velocities in the uppermost crust are undoubtedly a reflection of the fragmented nature of the EPR fabric-a process that apparently occurs near or at the margins of the EPR axial block as slivers of crust spall off the margins and become incorporated into the fabric. Hence, we predict that severe drilling difficulties will be encountered wherever reliable upper crustal seismic velocities are significantly lower than the measured velocities in equivalent basalts.

\section{ACKNOWLEDGMENT}

Shore-based work done at UCLA was supported by ERDA Grant E (04-3) 34 PA 224.

\section{REFERENCES}

Anderson, O. L., 1972. Patterns in elastic constants of minerals important to geophysics. In Robertson, E. C., Hays, J. F., and Knopoff, L. (Eds.)., The Nature of the Solid Earth: New York (McGraw-Hill), p. 575-613.

Birch, F., 1961. The velocity of compression waves in rocks to $10 \mathrm{~Kb}$, Part II, J. Geophys. Res., v. 66, p. 2199-2224. 
Christensen, N. and Salisbury, M. H., 1973. Velocities, elastic moduli and weathering-age relations for Pacific Layer 2 basalts, Earth Planet. Sci. Letts., v. 19, p. 461-470.

Christensen, N. and Shaw, G. M., 1970. Elasticity of mafic rocks from the Mid-Atlantic Ridge, Geophys. J. Roy. Astron. Soc., v. 120, p. 271-384.

Mattaboni, P. and Schreiber, E., 1967. Improved method of pulse transmission measurements for determining sound velocities, J. Geophys. Res., v. 72 (20), p. 5160-5163.

O'Connell, R. J. and Budiansky, B., 1974. Seismic velocities in dry and saturated cracked solids, Ibid., v. 79, p. $5412-5426$.

Orcutt, J. A., Kennett, B. L. N., and Dorman, L. M., 1976. Structure of the East Pacific Rise from an ocean bottom seismometer survey, Geophys. J. Roy. Astron. Soc., v. 45, p. 305-320.
Schreiber E. and Anderson, O. L., 1970. Properties and composition of lunar materials: Earth analogies, Science, v. 168 , p. $1579-1580$.

Walsh, J. B., 1965. The effect of cracks on the uniaxial elastic compression of rock, J. Geophys. Res., v. 70 (2), p. 399411.

Warren, N., 1977. Characterization of modulus-pressure systematics of rocks: Dependence on microstructure. In Heacock, J. (Ed.), The Earth's Crust: Washington, D. C. (American Geophysical Union), Monograph \#20, p. 119148.

Warren, N. and Nashner, R., 1976. Theoretical calculations of compliances of a porous medium. In Runckorn, K. (Ed.), The Physics and Chemistry of Minerals and Rocks: New York (John Wiley), p. 197-216. 